\title{
Concomitant Medication Start Date
}

National Cancer Institute

\section{Source}

National Cancer Institute. Concomitant Medication Start Date. NCI Thesaurus. Code C83124.

The date on which the concomitant medication usage begins. 